IJMS 2017 vol. 4 (2): $55-63$

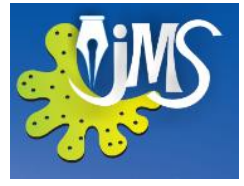

\title{
National Security of Sri Lanka: Importance of Mass Media and Communication
}

\author{
Senaratne B \\ Department of Strategic Studies, Faculty of Defence \& Strategic Studies, \\ General Sir John Kotelawala Defence University, Sri Lanka
}

\begin{abstract}
This decade is proving to be crucial to national security of Sri Lanka as there are many international pressures upon the country. Some of these pressures are legal whilst others are economic. However, the common nature of all these pressures is that it threatens Sri Lanka's national security and obstructs the development of the country. Therefore it is imperative that Sri Lanka conducts itself in a manner that safeguards the country's national security. In this context, this research highlights the importance played by mass media and communication in safeguarding Sri Lanka's national security and interests. The research thus provides an analysis of mass media in reporting international pressures on Sri Lanka. It will also analyse the media relations of the Ministry of Foreign Affairs against these international pressures. Towards this end, the research mainly utilises secondary data such as newspaper articles, press releases, feature articles from reputed websites and reports from social media etc. The research will also analyse media relations against existing communication models among others Shannon - Weaver and Defleur and identify a mechanism that will help safeguard Sri Lanka's image. The research identified there is a communication gap and that mass media is not being utilised appropriately by the relevant authorities in presenting and projecting the image of Sri Lanka. In conclusion, the research provides a communication tool for the Ministry of Foreign Affairs to follow when interacting with the media both local and international in order to safeguard Sri Lanka's national security. It also highlights the importance of social media and its uses in the future and finally provides a link to the interconnectedness of national security and mass media as they both together assist with the development of the country.
\end{abstract}

KEYWORDS: Foreign affairs, national security, mass media and communication

Corresponding author: B. Senaratne, Email: bhagya.senaratne@kdu.ac.lk 


\section{INTRODUCTION}

This decade is proving to be crucial to Sri Lanka's National Security as there are many international pressures upon the country. These pressures appear to threaten Sri Lanka's position as a sovereign entity in the global sphere. Some of these pressures can be categorised as juridical, whilst others are economic and military in nature. But the common nature of all these influences is that it threatens Sri Lanka's national security and obstructs the development of the country. In this context it is imperative that Sri Lanka conducts itself in a manner that safeguards the country's national security whilst acting in a manner that befits the state's internal political structure.

Nations in both the East and West such as the Chinese Dynasties, the Indian Kingdoms, the Roman Empire and Ptolemaic Egypt utilised the services and assistance of ambassadors to connect and communicate with faraway lands and kingdoms. Whilst establishing political connections with these lands, the ambassadors were also tasked to project the best image of the place they were representing and promote its culture (Vienna Convention on Diplomatic Relations). With this commenced the history of traditional diplomacy. Modern diplomacy can be dated to 1815 when the Congress of Vienna was held. The Cambridge Learner's Dictionary \& Thesaurus defines diplomacy as "the management of relationships between countries." History depicts the importance of managing relations with other states, which will in turn assist in safeguarding the national security of the country.

\section{BACKGROUND}

\subsection{National Security}

The legal definition provided by the US Legal refers to national security as having armed forces to ensure its physical borders are not threatened and safeguarding a state's secrets.
The term entails within itself both traditional and non-traditional aspects of security (US Legal, n.d.). The term can further be defined as a position that exists due to "military or defense advantage over any foreign nation or group of nations, or a friendly foreign relations position, or a defense position capable of successfully protesting hostile or destructive action" (US Legal, n.d.). Thus, it shows that these are areas of concern for Sri Lanka when seeking to protect its national security. Not only does the term emphasize that it is the foundation of freedom and prosperity within a nation, it also underscores sovereignty and territorial integrity. Papp and Alberts define national security as

"... the protection of a state, its territories, and its peoples from physical assault by external forces, as well as the protection of important state economic, political, military, social, cultural, and valuative interest from attacks emanating from foreign or domestic sources which may undermine, erode or eliminate these interests, thereby threatening the survival of the state" (2000, p. 245).

The duo state that both military and non-military means are utilised to protect and safeguard national security (Papp and Alberts, 2000). It is thus clear that the concept of national security is broad and that it has no clear and precise boundaries. However, factors such as wealth, geography and military force affect and influence this broad concept (Griffiths, 2008). Further, as media discusses about economic, political and socio-cultural factors, it is important to understand that these too are responsible in safeguarding a country's national security.

\subsection{Public Communication, Models and its uses}

Models of communication enable the explanation of the human communication process in a theoretical manner. The first major model for communication was defined in 1949 by Claude Elwood Shannon and Warren 
Weaver. Melvin Lawrence De Fleur expands the Shannon \& Weaver model of communication by inserting the Mass Media device and suggesting the communication process is circular as it creates an avenue for possible two way feedback. Whilst noise may occur at any stage of the communication process, Defleur assigns the source, transmitter, receiver and destination as separate phases of mass communication. He also included the "Feedback Device" to his communication model which helps analyse the target audience (as separate from the receivers). One of the important aspects of the communication model is the two way communication process which is recommended by Defleur. This model is important as it is the first to introduce both two way feedback and targeted audience in the communication process (Communication Theory, n.d.).

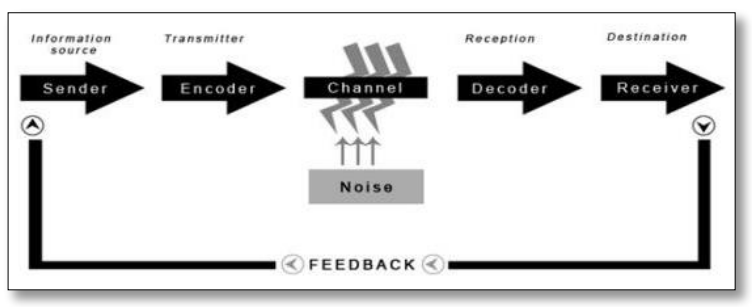

Figure 1: Shannon and Weaver Model of Communication

Source: Communication Theory

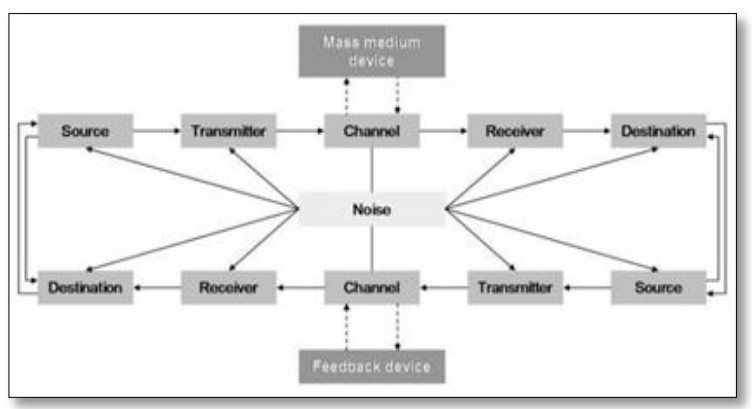

Figure 2: Defleur Model of Mass Communication System

Source: Communication Theory

The two models discussed above are important in understanding the context in which Sri Lanka's representatives stationed both in the country and abroad are interacting with and understand the media to work hand-in-hand with them to produce both a positive image as well as to counter negative reportage on the country.

\section{RESEARCH METHODOLOGY}

The research objective was to demonstrate the importance of mass media and communication in safeguarding Sri Lanka's national security. The research questions formulated for this study were to identify the contribution of mass media in safeguarding the country's national security and the importance of communicating a message to counter opposing views. Primary data for the research was gathered through policy documents and interviews, government press releases and communiqués, speeches, United Nations' website and government websites especially that of the Ministry of Foreign Affairs. Secondary data for the research was obtained through journals, newspaper feature articles and commentaries.

Data analysis and selective coding were carried out by using grounded theory taking the 'importance of mass media and communication' as the core category and 'foreign policy' and 'national security' as the sub-categories. For research purposes, the study has identified three incidents pertaining to Sri Lanka, namely the Humanitarian Operation conducted by the Sri Lanka Military in 2009, the United Nations Human Rights Council (UNHRC) Resolution on Sri Lanka in 2012, and Jon Snow's Sri Lanka's Killing Fields: War Crimes Unpunished in 2012 that were visibly used to threaten the national security of the island-nation.

The research will provide a thorough analysis on how mass media including social media have reported these incidents. They will be analysed against the two communication models derived by Claude Elwood Shannon \& Warren Weaver and Melvin Lawrence De Fleur. Therein, the conclusions and recommendations drawn are as a result of this analysis. 


\section{DISCUSSION}

National security was a key element in Sri Lanka's domestic politics since independence, even though Sri Lanka was a Dominion State till it forfeited its status in 1972. Prime Minister, D. S. Senanayake stated: "The defence of its country is one of the primary obligations of an independent state" (Keerawella \& Siriwardena, 1992). Since the 1970s national security featured prominently in the list of priorities in the Sri Lankan agenda (Karunaratne, 2017; Keerawella \& Siriwardena, 1992). This was because Sri Lanka witnessed internal revolts which threatened the country's peace and security as well as because Sri Lanka needed to fortify its security, having forfeited its Domion Status. Internal turmoil such as the rise of the LTTE and the second JVP insurrection caused further damage to Sri Lanka's national security and this was a cause for concern for the island-nation. The post-independence governments realised defence and security considerations were crucial and decisive factors in the country's foreign policy decision-making (Keerawella \& Siriwardena, 1992).

In the 1990s and the early 2000s the strength of the LTTE increased by leaps and bounds causing an immense threat to Sri Lanka's national security. It also continued to threaten the human security of all Sri Lankans, especially their food security when in 2006 the Maavillaru Sluice Gates were closed. This threat, led to the government launching its humanitarian operation which concluded with it defeating the terrorist group. Therefore, Sri Lanka's history and its present context need to be considered when understanding the responsibilities of the state in addressing its national security (Rajapaksa, 2013).

In the $21^{\text {st }}$ Century, the internet has come to play a very crucial part in the human life, making everyone a global citizen, with access and connectivity to other parts of the world. This convenience of access allows people to not only be informed of incidents that take place in areas beyond their homes, but to also communicate with those experiencing situations; both good and bad. In this context, the communication model derived by Defleur becomes extremely relevant and applicable. However, the model needs to be further developed to incorporate the ability of communication to influence not merely a segment of society, but to change entire governance systems. Thus, it can be established that mass media and communication tools such as technology driven new media such as blogs, wikis and social media sites such as Facebook, Twitter, Instagram of the current age are able to pose a threat towards Sri Lanka's national security. According to Rajapaksa (2013) "this is yet another threat that needs to be monitored."

This is of extreme importance due to the increasing penetration of the Internet and computer literacy in Sri Lanka. Due to this increase, many Sri Lankan youth are familiar with these new media tools and use them as a mechanism to gather information as well as propagate ideas. Thus, social media can be exploited to propagate certain ideologies online in order to mobilise and organise people. As there is no physical presence in this kind of mobilisation, it can be difficult to contain through traditional means of national defence (Rajapaksa, 2013).

\subsection{Humanitarian Operation conducted by the Sri Lankan Military in 2009}

The pro-LTTE elements utilise their defeat during the last phase of the war in Puthukkudiriruppu and Nanthikadal Lagoon to their benefit to seek sympathy for their loss. They showcase this stage of the war from March to May 2009 as genocide of Tamils by the Government of Sri Lanka. One of their chief mechanisms of propagating these sentiments is via visual means captured by the Nitharsanam Unit or the Battlefield Camera Unit. Their mission is to recreate the truth based on the lines of LTTE ideology for which they reframe the conflict over and over again (Defence Wire, 2008). 
Due to the success of the LTTE propaganda, media dominated by western nations have portrayed the final stage of war as being a violation of Human Rights (HR) and International Humanitarian Law (IHL). Various newspaper headlines as well as online news reports slandered the Government of Sri Lanka (GoSL). Media personnel who supported the terrorists presented fabricated news and reported erroneously on the Humanitarian Rescue Operation without verifying facts. They circulated stories of hospitals being shelled and evidence of unimaginable casualties via infographics, visual media as well as reports sent by the medical personnel and the Tamil INGO personnel in their midst. Samaraweera asserts, that many journalists paid by the LTTE visited Sri Lanka to write falsified news advantageous to them (2010). Whilst representatives from international organisations that visited the island in guise, declared that the camps for the Internally Displaced Persons (IDPs) were "concentration camps" (Samaraweera, 2010). It must be noted that the Northern and Eastern Provinces were not accessible to foreign media because of its security implications. Further in 2009 major foreign media networks in Western nations along with their emissaries such as the US Ambassador, accepted the casualty figures peddled by medical teams present in Sri Lanka during the war without any scepticism (Roberts, 2014). Social media users who empathised with these views were no less kind towards this reportage thereby promoting and sharing these views and commentaries.

The use of Defleur's model of communication can be seen used in these instances where a message is being sent by the source which is then received, interpreted and shared by the receiver. The model's unique feedback device too is at play here as the feedback for the incident can be identified by the number of times the news of the falsified propagation of the Humanitarian Operation were been spread and shared as the audio-visual media makes the fight for Eelam a personal experience of the viewer (who is often detached from reality) by recreating reality and truth within the confines of LTTE ideology. Further, the feedback witnessed here also shows how the large audience empathised with it, and thus were influenced by the message, which was not intended for them. It showcased that the reportage with the lack of verification and authenticity drew the attention of the United Nations and the Western world.

The research uncovered that all the photos the LTTE displayed as being of Tamil women and children killed by Sinhalese are photos taken after the LTTE butchered Sinhalese villagers during their ethnic cleansing. It is said that their video footage is posed and filmed using props and actors (De Silva, 2009). It can be identified that the LTTE propagandists understood the message they wanted to deliver and tools of communication for they were very effective in identifying their target audience. Although a few major incidents are shown in public TV and news media, most are person to person or by email contact. They even employed mass media psychologists to prepare the media releases. Today, with many of the youth in the Diasporas strongly believing in LTTE propaganda, it is easier for the organisation to carry out their work (De Silva, 2009). The LTTE propaganda arm was also skillful in eliminating the 'noise' factor described in Defleur's communication model by establishing credence to its dissemination by seeking the assistance and buying media personnel who are familiar to the public. "The efficacy of this method is evident in the extent to which the Tamil Diasporas, government officials and representations of international organizations believe this propaganda. For some reason, these people do not even think about questioning what they hear" (De Silva, 2009). It is this means of propagation and threat to national security the Government of Sri Lanka has and continues to face. Further as Papp and Alberts argues, "...advance information and communication technologies and the capabilities they provide are becoming an increasingly important factor in the national security..." (2000). Therefore the government 
has to pay more attention to the activities it carries out and understand that the increase in which the information is circulated will naturally intensify. Furthermore, the rate at which international actors interact with each other too will escalate, resulting in the government requiring to take necessary measures to address these changes in the information flow.

\subsection{United Nations Human Rights Council Resolution on Sri Lanka in 2012}

The UNHRC Resolution on Sri Lanka in 2012 was to a greater extent influenced by LTTE propaganda in the Western nations and the incidents mentioned in 4.1. The LTTE was tactful in forming allies in the western governments they had sought refuge during the inception of the war such as in Britain, Australia and the United States where they befriended Members of Parliament like Lee Scott and Nick De Bois, Senator Lee Rhiannon, the former Attorney General Ramsey Clark respectively who later joined the Transnational Government of Tamil Eelam (TGTE) and with international organisations. The resolution was also influenced by pro-LTTE elements targeting government officials through incidental meetings and entertainment, in order to familiarise the officials with the LTTE's version of incidents and crimes the Sri Lankan government has carried out. Contacts are created over time and sometimes even paid to speak for the LTTE (De Silva, 2009).

The emphasis on "merciless shelling" by the Government forces has been underlined and several international organisations and media agencies resorted to statistically illustrate the number of Tamil civilians who died. The UN Panel of Experts appointed by UN Secretary General Ban Ki-Moon and Navy Pillai which presented the Darusman Report in 2011 guesstimate 40,000 civilian dead as a "credible allegation" (Roberts, 2014). These report was deemed "credible" by Amnesty International, ICG and high profile media spokespersons (eg.
Kerry O'Brien of ABC) which is an incidental instance of messaging and dishonesty (Roberts, 2014). It is these falsified reportage that led to the passing of the UNHRC resolution in 2012. According to Samaraweera (2010), others from international organisations wrote reports based on data supplied by the same source, i.e. the proLTTE entities. Thus these organisations grouped to unethically create an atmosphere favourable to the LTTE, thereby failing in their responsibility to preserve the canons of justice and honest commitment.

Thus the research observed the use of Defleur's model of communication wherein the falsified messages issued by the pro LTTE elements having the desired effect on its receivers and influencing to the extent where the feedback received are detrimental to the GoSL by way of resolutions passed against the country in international fora.

\subsection{Jon Snow's Sri Lanka's Killing Fields: War Crimes Unpunished in 2012}

The LTTE's propaganda has gradually reached a wide audience in a number of foreign countries. It has also managed to influence international governmental organisations (IGOs) as well as non-governmental organisations (NGOs). De Silva asserts this was possible by "gradually infiltrating educated Tamils from the Diasporas into these organizations through job applications, often at very low levels in the organizations" (2009).

Many of these educated Tamils had sought economic refuge in these countries at the inception of the conflict in the 1980s (Bandarage, 2009). It is further argued that these Sri Lankan Tamil people now occupy high-level positions in the countries they settled in (Bandarage, 2009; De Silva, 2009). This enables them to be influencers in their countries' politics and governance as well as have the monetary capability to sponsor the LTTE's political activities. 
In this context, it was the responsibility of the local media to neutralise the malicious propaganda. Analytical media and social media reports such as 'Sri Lanka's War In Its Last Phase: Where WIA Figures Defeat The Gross KIA Estimates', 'The war in Sri Lanka and propaganda debates: An analysis for the OHCHR in Geneva' and 'Deadly Accountancy Part 2' helped counter the negative impact created on the country, thus helping to safeguard Sri Lanka's interests. As Samaraweera contends "with colourful editorials, articles and pictures the local media outmaneuvered these groups and counterbalanced western criticism of the conduct of the war" (2010). This showcases that it is important for the feedback device derived by DeFleur to be in place, to educate the public and individuals from international organisations about what was happening in Sri Lanka, to depict the real situation.

\section{CONCLUSION}

The three incidents discussed above and the related incidents discussed in this research showcase the length to which the LTTE propaganda has infiltrated society and global perceptions on the war and its ideology. Propaganda mechanisms of the LTTE such as the Nitharsanam Unit achieved something the entire Sri Lankan government has failed to achieve; a well-oiled propaganda machine capable of legitimizing itself through an audiovisual experience unlike anything they have ever witnessed. Units such as these and the massive propaganda mechanisms were funded by the money collected from the Sri Lanka Tamil Diasporas as well as the world community of Tamils, thus enabling them to be far more powerful and far-reaching than any media organisation in the world. This is because there were Sri Lankan Tamil economic refugees and their sympathisers around the world, willing to assist them.

To this end, whilst unbiased, analytical media reporting assists in creating a positive image of the country, it is not sufficient in safeguarding the national security of the country. The national security of a country assists with its future development. Therefore, whilst publishing news and statements which are beneficial for the country, the Government as well as the Ministry of Foreign Affairs has to advocate research scholars and academia to discuss and publish research articles and papers on this matter. Credible and unbiased materials are influential in mitigating the one-sided content propagated by the pro-LTTE elements. As it was observed that majority of the information countering the LTTE propaganda were from government sources, thus encouraging the public to believe it was biased. Therefore going forward, the government needs to increase sources friendly to it. Further, it is important for the government to identify this vacuum and circumvent it with a proper strategy.

During this research it was noted that the communication practiced by the Ministry of Foreign Affairs has been similar to that of the model derived by Shannon - Weaver, wherein there is no feedback from the audience. Further, besides the formal communication material released from the Ministry of Foreign Affairs, it needs to increase its interaction and engagement with the general public by incorporating the feedback criterion given in Defleur's communication model. Communication material derived and utilised for this purpose must be attractive and colourful, with the capacity to engage the intended audience.

The research identified that the Ministry's public communication and public diplomacy divisions need to be strengthened and modified to meet the needs and requirements of the $21 \mathrm{st}$ Century. The diplomats and the supporting staff need to be up-to-date with current trends in technology and skilled to counter and react to any negative messaging found on global media and particular social media. Whilst social media was not a prominent tool of the LTTE propaganda in the past, it certainly will be in the future. Therefore, the Ministry of Foreign 
Affairs needs to be proactive in its diplomatic endeavors to improve its engagement with the public in keeping with modern trends to safeguard Sri Lanka's national security and paint a positive image of Sri Lanka both internally and externally.

\section{REFERENCE}

BANDARAGE A. The Separatist Conflict in Sri Lanka: Terrorism, ethnicity, political economy. Oxon: Routledge. 2009.

CHANNEL 4. Sri Lanka's Killing Fields. (2012, March 14). Available in http://www.channel4.com/programmes/srilankas-killing-fields 2015. Accessed on $25^{\text {th }}$ of September 2015.

\section{CAMBRIDGE ADVANCED LEARNER'S} DICTIONARY \& THESAURUS. Diplomacy. 2015. Available in http://dictionary.cambridge.org/dictionary/engli $\mathrm{sh} /$ diplomacy? $\mathrm{q}=$ diplomacy+ Accessed on $23^{\text {th }}$ of September 2015.

COLVIN M. Artillery pounds wounded Tamils trapped on beach. Sunday Times. (2009, March 22). Available in http://definitions.uslegal.com/n/nationalsecurity/ Accessed on $28^{\text {th }}$ of September 2015.

COMMUNICATION THEORY. (n.d.) Available in http://communicationtheory.org Accessed on 22 ${ }^{\text {nd }}$ of September 2015.

DEFENCE WIRE. LTTE Propaganda: Nitharsanam Unit. 2008. Available in http://defencewire.blogspot.com/2008/03/lttepropaganda-nitharsanam-unit.html Accessed on $28^{\text {th }}$ of September 2015.

DE SILVA J. The Worldwide LTTE Propaganda Organization. Asian Tribune. (2009, April 18). Available in http://asiantribune.com/nodae/16865 Accessed on $23^{\text {rd }}$ of September 2015.
GHOSH P. International Relations. New Delhi: PHI Learning. 2015.

GRIFFITHS M. Encyclopaedia of International Relations and Global Politics. London: Routledge. 2008.

HIRU NEWS. Former US Attorney General Joins pro LTTE group. (2012, August 17). Available in http://www.hirunews.lk/41378/former-usattorney-general-joins-pro-ltte-group Accessed on $24^{\text {th }}$ of September 2015.

KARUNARATNE V. Country ran smoothly from 1948 to 1970. Ceylon Today. (2017, May 25). Available in http://www.ceylontoday.lk/print20170401CT20 170630.php?id=21716 Accessed on $30^{\text {th }}$ of May 2017.

KEERAWELLA $G$ \& SIRIWARDENA L. Internal Dynamics in the Evolution of Sri Lankan Defence Policy: Some Observations. In P.V.J. Jayasekera (Ed.), Security Dilemma of a Small State: Sri Lanka in the South Asian Context. New Delhi: South Asian Publishers. 1992; 234-255.

KISSINGER H. World Order: Reflections of the Character of Nations and the Course of History. UK: Penguin Books. 2014.

MANGO. Sri Lanka's War In Its Last Phase: Where WIA Figures Defeat The Gross KIA Estimates. Colombo Telegraph. 2014. Available https://www.colombotelegraph.com/index.php/ sri-lankas-war-in-its-last-phase-where-wiafigures-defeat-the-gross-kia-estimates/ Accessed on $23^{\text {rd }}$ of September 2015.

MINISTRY OF DEFENCE. Humanitarian Operation Factual Analysis: July 2006 - May 2009. Colombo: Ministry of Defence. 2011.

NIVUNHELLA S. Two pro-LTTE Conservative MPs defeated in British poll - Only 
one candidate of Lankan origin romps home. SriExpress. (2015, May 10). Available in http://www.sriexpress.com/news/uk/1537-twopro-ltte-conservative-mps-defeated-in-britishpoll-only-one-candidate-of-lankan-originromps-home.html Accessed on $23^{\text {rd }}$ of September 2015.

OFFICIAL GOVERNMENT NEWS PORTAL OF SRI LANKA. Australian MP expresses outrage over pro-LTTE comments. (2014, December 11). Available in http://www.news.lk/news/world/item/5014australian-mp-expresses-outrage-over-pro-lttecomments Accessed on $24^{\text {th }}$ of September 2015.

PAPP DS, DAVID SA. The New Look of National Security in the Information Age. In SF Krishna-Hensel (Ed.).The New Millennium: Challenges and Strategies for a Globalizing World. Ashgate: Aldershot. 2000. p. 241-262.

PADRAIG C. Deadly Accountancy Part 2. (2013, May 07). Available in https://pcolman.wordpress.com/2013/05/07/dea dly-accountancy-part-2/ Accessed on $23^{\text {rd of }}$ September 2015.

RAJAPAKSA G. Sri Lanka's National Security. PRISM 4. No. 4. National Defense University, USA: Center for Complex Operations. 2013. Available in http://www.defence.lk/news/pdf/Sir_Lankas_N ational_Security_corrected.pdf Accessed on $23^{\text {rd }}$ September 2015.

ROBERTS M. The war in Sri Lanka and propaganda debates: An analysis for the OHCHR in Geneva. Groundviews. (2014, July 11). Available in http://groundviews.org/2014/11/07/the-war-insri-lanka-and-propaganda-debates-an-analysisfor-the-ohchr-in-geneva/ Accessed on $23^{\text {rd }}$ of September 2015.

ROBERTS M. Misreading and Distorting the Sri Lankan War, 2009-2012, Thuppahi's Blog. (2012, May 25), Available in https://thuppahi.wordpress.com/2012/05/25/mis reading-and-distorting-the-sri-lankan-war2009-2012/ Accessed on 26 ${ }^{\text {th }}$ of September 2015.

SAMARAWEERA AP. International media and LTTE propaganda war- An Opinion. Ministry of Defence. (2010, December 30). Available in http://www.defence.lk/new.asp?fname $=200905$ 23_08 Accessed on $23^{\text {rd }}$ of September 2015.

TAMIL GUARDIAN. Revisiting May 2009 Civilians walk into SL camps after thousands killed in night of shelling, surrendering LTTE leadership killed, Tamils blockade Westminster. (2015, May 18). Available in http://www.tamilguardian.com/article.asp?articl art=9905 Accessed on $23^{\text {rd }}$ of September 2015.

US LEGAL. National Security Law and Legal Definition. 2015. Available in https://definitions.uslegal.com/n/nationalsecurity/ Accessed on $25^{\text {th }}$ of September 2015.

VIENNA CONVENTION ON DIPLOMATIC RELATIONS 1961. United Nations. 